\title{
Estimating water application efficiency for drip irrigation emitter patterns on banana
}

\author{
Alisson Jadavi Pereira da Silva(1), Eugênio Ferreira Coelho(2), Jarbas Honorio de Miranda ${ }^{(3)}$ \\ and Stephen Ray Workman ${ }^{(4)}$
}

\begin{abstract}
(1)Universidade de São Paulo (USP), Escola Superior de Agricultura Luiz de Queiroz (Esalq), Departamento de Engenharia Agrícola, Avenida Pádua Dias, no 11, CEP 13418-900 Piracicaba, SP, Brazil. E-mail: ajpsilva@esalq.usp.br (2)Embrapa Mandioca e Fruticultura Tropical, Rua Embrapa, s/nº, CEP 44380-000 Cruz das Almas, BA, Brazil. E-mail: eugenio@cnpmf.embrapa.br (3)USP, Esalq, Departamento de Ciências Exatas. E-mail: jhmirand@esalq.usp.br ${ }^{(4)}$ Biosystems and Agricultural Engineering, Department of Biosystems and Agricultural Engineering, 105 C.E. Barnhart BIdg, Lexington, KY, USA 40546-0276. E-mail: sworkman@bae.uky.edu
\end{abstract}

\begin{abstract}
The objective of this work was to evaluate root and water distribution in irrigated banana (Musa sp.), in order to determine the water application efficiency for different drip irrigation emitter patterns. Three drip emitter patterns were studied: two 4-L h $h^{-1}$ emitters per plant (T1), four 4-L $\mathrm{h}^{-1}$ emitters per plant (T2), and five 4- $\mathrm{L} \mathrm{h}^{-1}$ emitters per plant (T3). The emitters were placed in a lateral line. In the treatment T3, the emitters formed a continuous strip. The cultivated area used was planted with banana cultivar BRS Tropical, with a 3-m spacing between rows and a $2.5-\mathrm{m}$ spacing between plants. Soil moisture and root length data were collected during the first production cycle at five radial distances and depths, in a $0.20 \times 0.20 \mathrm{~m}$ vertical grid. The experiment was carried out in a sandy clay loam Xanthic Hapludox. Soil moisture data were collected every 10 min for a period of five days using TDR probes. Water application efficiency was of 83,88 and $92 \%$ for the systems with two, four and five emitters per plant, respectively. It was verified that an increase in the number of emitters in the lateral line promoted better root distribution, higher water extraction, and less deep percolation losses.
\end{abstract}

Index terms: Musa spp., root distribution, rootzone processes, TDR, water use efficiency.

\section{Estimativa da eficiência de aplicação de água em bananeira com diferentes sistemas de gotejamento}

\begin{abstract}
Resumo - O objetivo deste trabalho foi avaliar a distribuição de água e raízes de bananeira (Musa sp.) irrigada, para determinar a eficiência de aplicação de água por diferentes sistemas de irrigação por gotejamento. Foram estudados três sistemas de gotejamento: T1, dois emissores de $4 \mathrm{~L} \mathrm{~h}^{-1}$ por planta; T2, quatro emissores de $4 \mathrm{~L} \mathrm{~h}^{-1}$ por planta; e T3, cinco emissores de $4 \mathrm{~L} \mathrm{~h}^{-1}$ por planta. Os emissores foram dispostos em uma linha lateral. No tratamento T3, os emissores formaram uma faixa contínua. A área de cultivo foi plantada com bananeira cultivar BRS Tropical com espaçamento de $3 \mathrm{~m}$ entre fileiras e de 2,5 m entre plantas. Dados de umidade e comprimento de raízes foram coletados durante o primeiro ciclo da cultura, em cinco distâncias radiais e profundidades, em uma malha vertical de $0,20 \times 0,20 \mathrm{~m}$. O solo da área experimental era um Latossolo Amarelo franco-argilo-arenoso. Os dados de umidade foram coletados em intervalos de $10 \mathrm{~min}$ por um período de cinco dias com uso de sondas de TDR. A eficiência de aplicação de água foi de 83,88 e $92 \%$ para os sistemas com dois, quatro e cinco emissores por planta, respectivamente. O incremento no número de emissores na linha lateral promove melhor distribuição radicular, maior extração de água e menores perdas por percolação profunda.
\end{abstract}

Termos para indexação: Musa spp., distribuição radicular, processos radiculares, TDR, eficácia na utilização da água.

\section{Introduction}

Banana is the most consumed (30 kg per habitant) and the second most produced fruit in Brazil (Anuário Brasileiro de Fruticultura, 2008). Despite these attributes, there still exist large technical issues to be solved concerning banana irrigation. The crop is sensitive to water stress and irrigation is necessary to provide suitable soil water content during banana's entire production cycle (Coelho et al., 2005). Water stress during flowering and fruit growth might be one of the main reasons for low average yield (14.1 $\left.\mathrm{Mg} \mathrm{ha}^{-1}\right)$ of banana in Brazil (Food and Agriculture Organization of the United Nations, 2007). Water use efficiency should be evaluated along with irrigation, since globally irrigated agriculture demands about $2,500 \mathrm{~km}^{3}$ of water per year, which is much greater than industrial (around $117 \mathrm{~km}^{3}$ ) or domestic uses $\left(64.5 \mathrm{~km}^{3}\right)$ (Sophocleous, 2004).

Pesq. agropec. bras., Brasília, v.44, n.7, p.730-737, jul. 2009 
The causes for low efficiency of water use in agriculture are numerous, complex and involve engineering, environmental, biological, social, and economical factors (Hsiao et al., 2007). Difficulties in determining some parameters, such as deep percolation losses, water potential gradients, and unsaturated soil hydraulic conductivity (Rogers et al., 1997) are limitations in calculating water application efficiency $\left(\mathrm{E}_{\mathrm{w}}\right)$.

Time domain reflectometry (TDR) measurements of soil water content have become a standard for studies that involve temporal and spatial water processes in soils, mainly due to their accuracy and automation (Heimovaara et al., 2004). They have commonly been used by many authors (Mmolawa \& Or, 2000; Heimovaara et al., 2004; Ritter et al., 2005) for water balance calculations in porous media.

The objective of this work was to evaluate root and water distributions in irrigated banana (Musa sp.), in order to determine the water application efficiency for different drip emitter patterns.

\section{Materials and Methods}

The work was carried out at Embrapa Mandioca e Fruticultura Tropical, in Cruz das Almas, BA, Brazil $\left(12^{\circ} 48^{\prime} \mathrm{S} ; 39^{\circ} 06^{\prime} \mathrm{W} ; 225 \mathrm{~m}\right.$ altitude). The area has an average annual rainfall rate of $1,143 \mathrm{~mm}$. A cultivated area with banana (Musa sp.) cultivar BRS Tropical in a $3 \times 2.5-\mathrm{m}$ spacing was used. Data were collected for five days during the first cycle of production in January 2006. The experiment was carried out in a sandy clay loam soil classified as Latossolo Amarelo (Xanthic Hapludox), whose physical characteristics (Claessen, 1997) are shown in Table 1.

Three different drip emitter patterns were studied: two 4-L h ${ }^{-1}$ emitters per plant (T1), four 4- $\mathrm{L} \mathrm{h}^{-1}$ emitters per plant (T2), and five 4- $\mathrm{L} \mathrm{h}^{-1}$ emitters per plant (T3), all placed in a lateral line. Treatment $\mathrm{T} 3$ formed a continuous strip of emitters. The experimental plots had ten plants, but the data acquisition system was installed around a single one due to limitations of the equipment in terms of number of multiplexers. The water volume applied per plant was the same in all treatments, based on the wetted area (Keller \& Bliesner, 1990) and on crop evapotranspiration considering crop coefficients suggested by Doorembos \& Kassam (1994). The irrigation was carried out daily, during the five days of the data collection period. Cultivation was done by conventional means and followed the soil fertilization recommended by Cordeiro et al. (2000). Nitrogen, potassium, and phosphorus were applied weekly by fertigation.

The soil moisture was monitored at five radial distances (r) and depths (z), in a $0.20 \times 0.20 \mathrm{~m}$ vertical grid measured from the plant and following its row direction. Time domain reflectometry (TDR) probes were installed horizontally in several points of the grid.

The TDR probes with three $0.1-\mathrm{m}$ long rods were made at Laboratório de Irrigação e Fertirrigação, at Embrapa Mandioca e Fruticultura Tropical, and calibrated according to the equation $\theta=6.438 \varepsilon^{3}-5.5246 \varepsilon^{2}+2.0373 \varepsilon-0.0745$, in which $\theta$ is the volumetric soil moisture and $\varepsilon$ is the soil dielectric constant.

During the installation of the TDR probes, $500 \mathrm{~cm}^{3}$ soil samples with roots were removed from the soil profile following the same installation grid of the TDR probes for determining the crop's root distribution. The roots were separated from the soil by washing (Bohm, 1979) and were digitized by scanning (Coelho et al., 2005). The root length (Lr) was obtained using the software Rootedge (Kaspar \& Ewing, 1997). The effective root depth and distance were established as those at the border of the root zone with at least $80 \%$ of the total root length. Soil moisture readings started 30 days after probe installation, which was the necessary time for the soil to stabilize the moisturization. Soil moisture data were collected every ten minutes for a period of five days. The TDR probes used a data acquisition system composed of TDR 100 equipment and a CR10X datalogger. The infiltrated water depth (LTI) after irrigation and the extraction water depth (LTE) from the system were computed based on soil water content data measured

Table 1. Soil physical characteristics of the experimental area, Cruz das Almas, BA, Brazil.

\begin{tabular}{|c|c|c|c|c|c|c|c|c|c|}
\hline \multirow[t]{2}{*}{ Depth (m) } & \multirow[t]{2}{*}{ Sand } & \multirow[t]{2}{*}{ Silt } & \multirow[t]{2}{*}{ Clay } & \multicolumn{2}{|c|}{$\begin{array}{c}\text { Porosity } \\
(\%)\end{array}$} & \multirow[t]{2}{*}{$\begin{array}{l}\text { Bulk density } \\
\left(\mathrm{kg} \mathrm{dm}^{-3}\right)\end{array}$} & \multicolumn{2}{|c|}{$\begin{array}{l}\text { Water retention } \\
\left(\mathrm{m}^{3} \mathrm{~m}^{-3}\right)\end{array}$} & \multirow[t]{2}{*}{$\begin{array}{l}\text { Hydraulic conductivity } \\
\qquad\left(\mathrm{m} \mathrm{s}^{-1} \times 10^{-7}\right)\end{array}$} \\
\hline & & & & Macro & Micro & & $-10 \mathrm{kPa}$ & $-1,500 \mathrm{kPa}$ & \\
\hline $0.0-0.2$ & 57.7 & 9.9 & 32.4 & 13.34 & 26.34 & 1.50 & 0.2106 & 0.14955 & 160 \\
\hline $0.2-0.4$ & 51.7 & 8.9 & 39.4 & 11.91 & 28.44 & 1.48 & 0.2401 & 0.17094 & 45.28 \\
\hline $0.4-0.6$ & 49.3 & 37.4 & 37.4 & 11.92 & 26.14 & 1.52 & 0.2195 & 0.16249 & 200.00 \\
\hline
\end{tabular}


at specific times: $(\mathrm{k})$ immediately before the irrigation, $(\mathrm{k}+1)$ when soil water content reached its maximum value at shallow locations $\left(\mathrm{r}_{\mathrm{i}}, \mathrm{z}_{\mathrm{j}}\right)$ and the wetting front reached the depth of $0.9 \mathrm{~m}$, and $(\mathrm{k}+2)$ at the time of the next irrigation (Figure 1).

Once these times were defined, the difference between the soil water content data after irrigation $\left(\theta_{\mathrm{k}+1}\right)$ and before irrigation $\left(\theta_{\mathrm{k}}\right)$ allowed the determination of the water depth infiltrated over time $(\mathrm{k}+1)-(\mathrm{k})$ in each position of the profile $\left(r_{i}\right)$ : LTI $=\int_{0}^{L} \theta_{k+1}\left(Z-\theta_{k}(Z) d z\right.$, where: LTI is the infiltrated water depth at each $\mathrm{r}_{\mathrm{i}} ; \theta_{\mathrm{k}+1}(\mathrm{Z})$ is the soil water content after irrigation at each $r_{i}$; and $\theta_{k}(Z)$ is the soil water content before irrigation at each $r_{i}$.

The average infiltrated water depth in a control volume of the banana root zone was determined using $\mathrm{LTI}_{\mathrm{m}}=\sum_{\mathrm{i}=1}^{\mathrm{n}} \operatorname{LTI}_{\mathrm{i}} / \mathrm{n}$, where: $\mathrm{LTI}_{\mathrm{m}}$ is the total average infiltrated water depth; LTI is the infiltrated water depth in each $r_{i}$; and $i$ is the index standing for the number of horizontal distances from the plant.

The difference between the soil water content values measured after the irrigation $(\mathrm{k}+1)$ and before the next irrigation $(\mathrm{k}+2)$ in a grid point $\left(\mathrm{r}_{\mathrm{i}}, \mathrm{z}_{\mathrm{j}}\right)$ allowed the extracted water depth to be determined at each point: $\mathrm{LTE}=\int_{0}^{\mathrm{L}} \theta_{\mathrm{k}+1}(\mathrm{Z})-\theta_{\mathrm{k}+2}(\mathrm{Z}) \mathrm{dz}$, where: LTE is the extracted water depth in each $r_{i}$ grid position; $\theta_{k+1}(Z)$ is the soil water content after irrigation in each $r_{i}$ grid position,

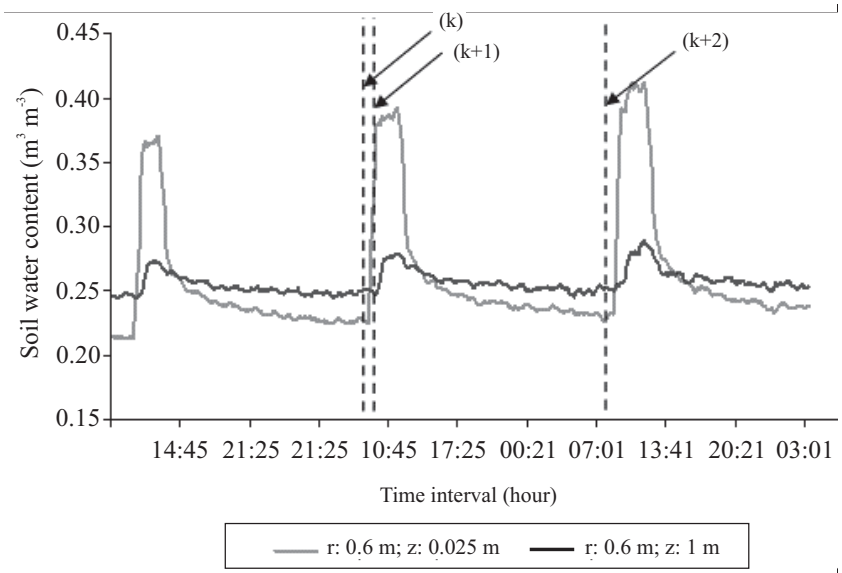

Figure 1. Soil water content at specific times: (k), immediately before the irrigation; $(\mathrm{k}+1)$, when soil water content got the maximum value at shallow locations $\left(\mathrm{r}_{\mathrm{i}}, \mathrm{z}_{\mathrm{j}}\right)$ and the wetting front reached the depth of $0.9 \mathrm{~m} ;(\mathrm{k}+2)$, the time of the next irrigation. and $\theta_{\mathrm{k}+2}(\mathrm{Z})$ is the soil moisture before next irrigation in each $r_{i}$ grid position.

The total average water depth extracted was obtained according to $\mathrm{LTE}_{\mathrm{m}}=\sum_{\mathrm{i}=1}^{\mathrm{n}} \mathrm{LTE}_{\mathrm{i}} / \mathrm{n}$.

The measured plant root distribution was used to define the root effective depth as the depth at which $80 \%$ of the total roots were concentrated. Losses by deep percolation were calculated for each point $\left(\mathrm{r}_{\mathrm{i}}, \mathrm{Z}_{\mathrm{j}}\right)$ located below the root effective depth: $\mathrm{DP}=\int_{\mathrm{k}+1}^{\mathrm{k}+2} \mathrm{qdt}$, where: $q=(\theta-\theta / t)(V / A), V$ is the soil volume corresponding to the probe insertion in the soil $(0.2 \times 0.2 \times 0.10 \mathrm{~m}), \mathrm{A}$ is the section area in relation to the probe insertion in the soil $(0.2 \times 0.2 \mathrm{~m}), \mathrm{t}$ is the time interval ( 1 hour), $\mathrm{q}$ is the water volume which passes through the unit area $\mathrm{A}$ in 1-hour time, $\theta$ is the soil water content at $\left(\mathrm{r}_{\mathrm{i}}, \mathrm{z}_{\mathrm{j}}\right)$ at time $\mathrm{k}$, and $\theta^{\prime}$ is the soil water content at $\left(\mathrm{r}_{\mathrm{i}}, \mathrm{z}_{\mathrm{j}}\right)$ at time $\mathrm{k}+1$.

In this sense, losses by deep percolation in the soil profile were obtained by $\mathrm{DP}_{\mathrm{m}}=\sum_{\mathrm{i}=1}^{\mathrm{n}} \mathrm{DP}_{\mathrm{i}} / \mathrm{n}$. The values of $\mathrm{DP}_{\mathrm{m}}$ at different times after the beginning of irrigation (AI) for T1, T2 and T3 were compared by $\mathrm{t}$ test (LSD) at $5 \%$ probability.

The average water application efficiency $\left(E_{a}\right)$ was: $\mathrm{E}_{\mathrm{a}}=\left(\mathrm{LTE}_{\mathrm{m}}-\mathrm{DP}_{\mathrm{m}}\right) / \mathrm{LTI}_{\mathrm{m}}$.

\section{Results and Discussion}

The effective root depth and distance observed in treatment $\mathrm{T} 1$ were 0.5 and $0.6 \mathrm{~m}$, respectively. These values were a little larger for treatment $\mathrm{T} 2$, with an effective depth and distance of 0.65 and $0.70 \mathrm{~m}$, respectively. For T3, the effective root depth and distance were 0.35 and $0.75 \mathrm{~m}$, respectively. These results are in agreement with Garcia (2000), Ramos (2001) and Borges et al. (2008). Eighty percent of the total water extracted by the roots took place at a zone limited by $\mathrm{r}=0.25 \mathrm{~m}$ and $\mathrm{z}=0.40 \mathrm{~m}$, for $\mathrm{T} 1$. In $\mathrm{T} 2$, root activity was extended in the soil profile compared to $\mathrm{T} 1$, and about $80 \%$ of the water extraction occurred in the zone limited by $r=0.50 \mathrm{~m}$ and $\mathrm{z}=0.35 \mathrm{~m}$. In T3, this zone was limited by $\mathrm{r}=0.55 \mathrm{~m}$ and $\mathrm{z}=0.35 \mathrm{~m}$. As observed by Andreu et al. (1997), the zones of water extraction were influenced by the placement of emitters around the plant. The increase in the number of emitters was followed by an increase of effective distance of the plants' water extraction zone. Moreover, the effective distances and depths of water extraction zones of roots were smaller than the effective root distances and 
depths. This result is in agreement with Green et al. (2006) and should be considered in irrigation schedules that use soil water sensors, since the effective zones of water extraction are commonly indicated for sensor placement in the field (Coelho et al., 2007).

The variations of available soil water (Figure 2) were more intense in the area limited by the dashed lines, in all treatments. The zones of water extraction

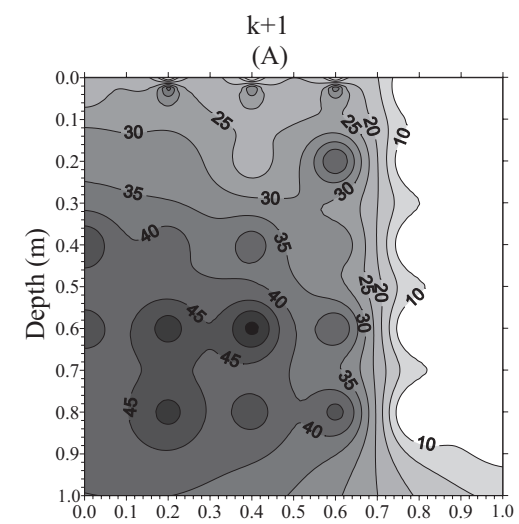

(B)

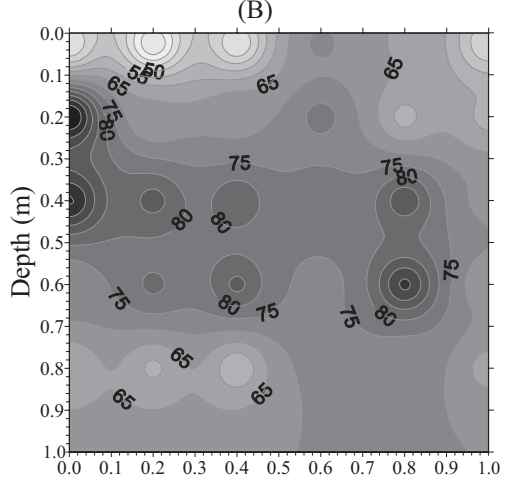

(C)

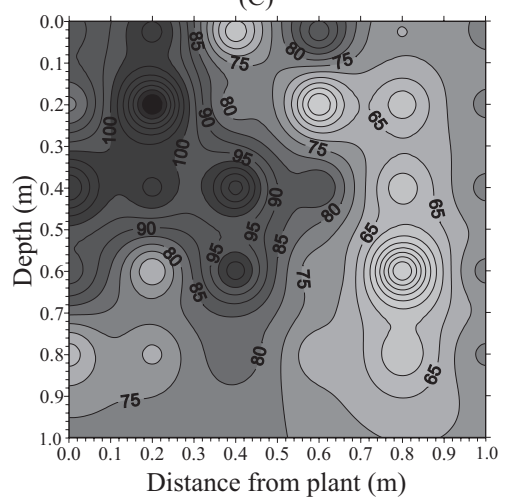

showed larger soil-available water at time $(\mathrm{J}+1)$, what is in accordance with the results obtained by Coelho \& Or (1999) and Santos et al. (2005).

Most of the water extraction occurred at radial distances of 0 to $0.6 \mathrm{~m}$ in $\mathrm{T} 1$, and $81.2 \%$ of the total root length was found in this region (Figure 3). Most of the soil water distribution took place near the pseudostem and did not extend beyond a radial

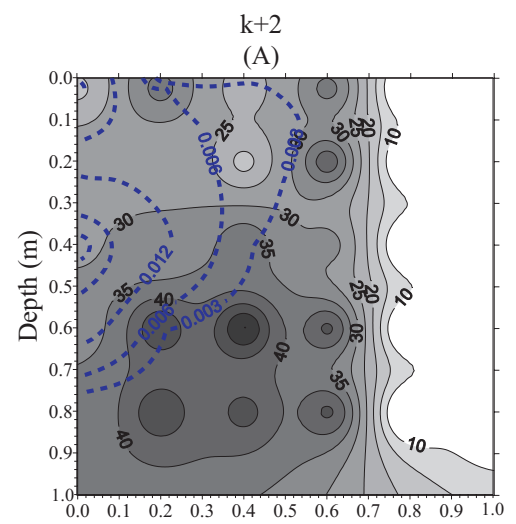

(B)

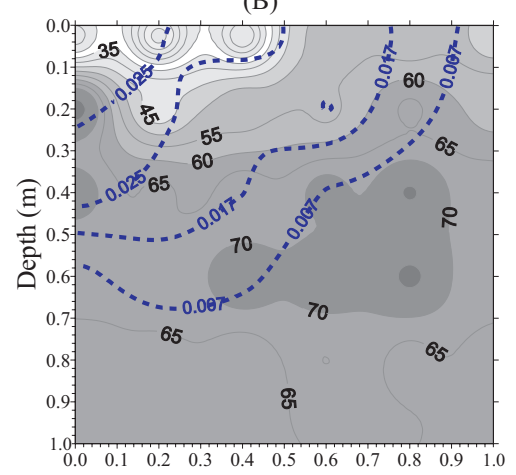

(C)

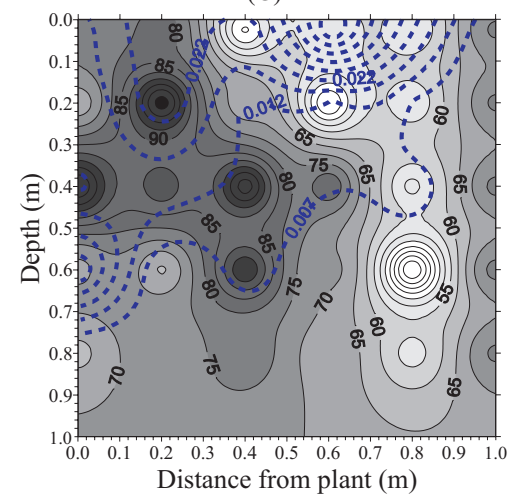

Figure 2. Available water (\%) in the soil profile at $\mathrm{k}+1$ (water content got the maximum value at shallow locations and the wetting front reached the depth of $0.9 \mathrm{~m}$ ) and $\mathrm{k}+2$ (time of the next irrigation) times for treatments T1 (A, two 4-L h ${ }^{-1}$ emitters per plant), T2 (B, four 4- $\mathrm{L} \mathrm{h}^{-1}$ emitters per plant) e T3 (C, five 4-L h ${ }^{-1}$ emitters per plant). Dashed lines at time $(\mathrm{k}+2)$ indicate zones of water extraction. 
distance (r) of $0.6 \mathrm{~m}$ for $\mathrm{T} 1$. This is consistent with the emitter placement at $0.2 \mathrm{~m}$ from the plant. Most of the deep percolation $(2.82 \mathrm{~mm})$ occurred at a radial distance of $0.2 \mathrm{~m}$ from the pseudostem. The average deep percolation $\left(\mathrm{DP}_{\mathrm{m}}\right)$ observed for this treatment was $1.36 \mathrm{~mm}$ (Figure 4).

The emitter location had strong influence on water extraction and root distribution in the wetted volume in T1. This result is in agreement with several studies that involved root and water distribution under drip irrigation systems (Coelho \& Or, 1999; Santos et al., 2005; Silva et al., 2006). The water application efficiency (Ea) for T1 was $82.7 \%$.

In T2, a different distribution of roots in the soil profile around the pseudostem was observed (Figure 3). Roots and water distribution in T2 extended to a larger
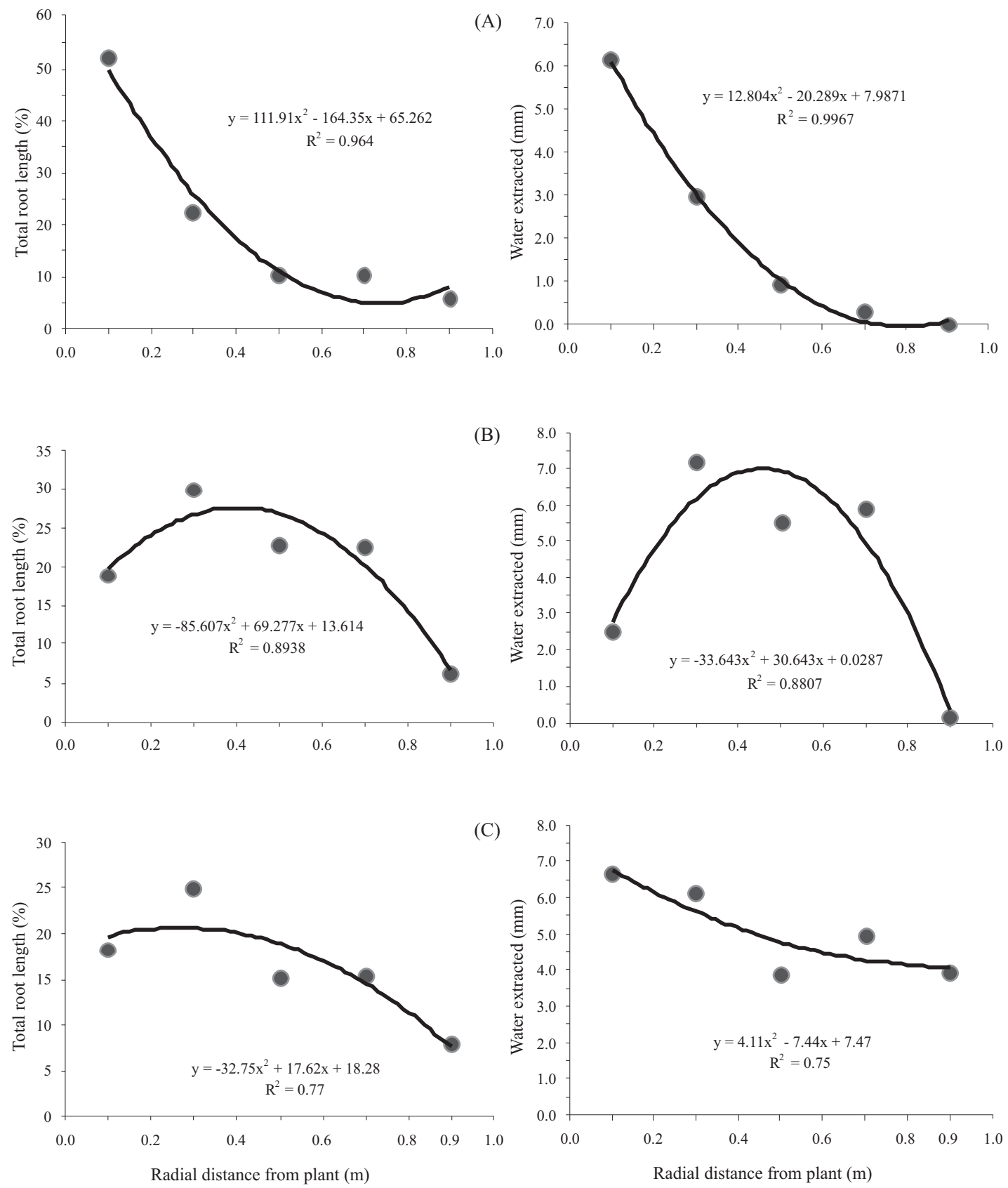

Figure 3. Total root length and water extracted at different horizontal distances (r) from the pseudostem, for treatment T1 (A, two 4- $\mathrm{L} \mathrm{h}^{-1}$ emitters per plant); T2 (B, four 4- $\mathrm{L} \mathrm{h}^{-1}$ emitters per plant); and $\mathrm{T} 3$ (C, five 4- $\mathrm{L} \mathrm{h}^{-1}$ emitters per plant) at different horizontal distances from the pseudostem. 
horizontal distance in the soil profile when compared to $\mathrm{T} 1$. The deep percolation losses were $18.4 \%$ smaller than the ones obtained in T1 (Figure 4). As a consequence, water application efficiency increased to $88.1 \%$.

There were deep percolation losses in all evaluated systems. The average values of percolated water depth at different times after the beginning of irrigation (AI) for $\mathrm{T} 1, \mathrm{~T} 2$ and $\mathrm{T} 3$ are in Table 2. Values of percolated water depth varied significantly according to the configuration of the irrigation system during the first hour after the beginning of irrigation (AI), and no significant difference among the average values of percolated water depth was verified during

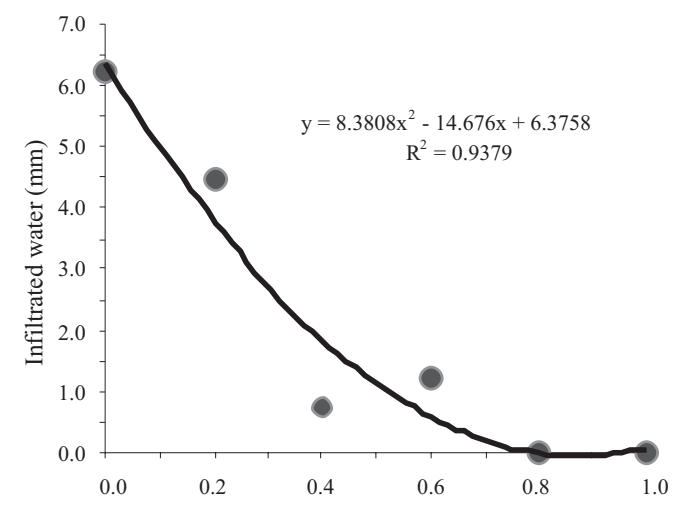

(A)

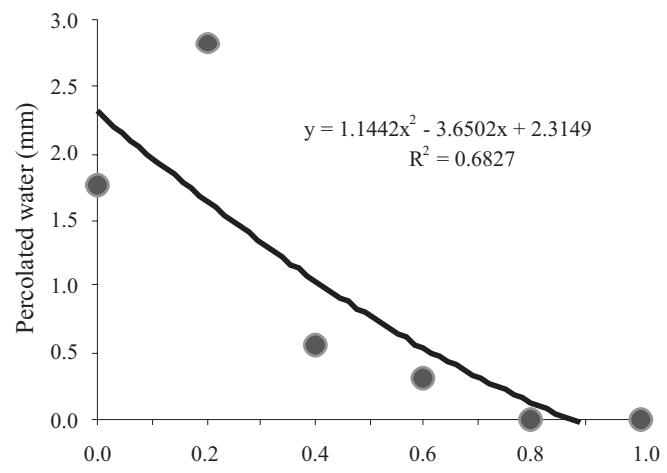

(B)
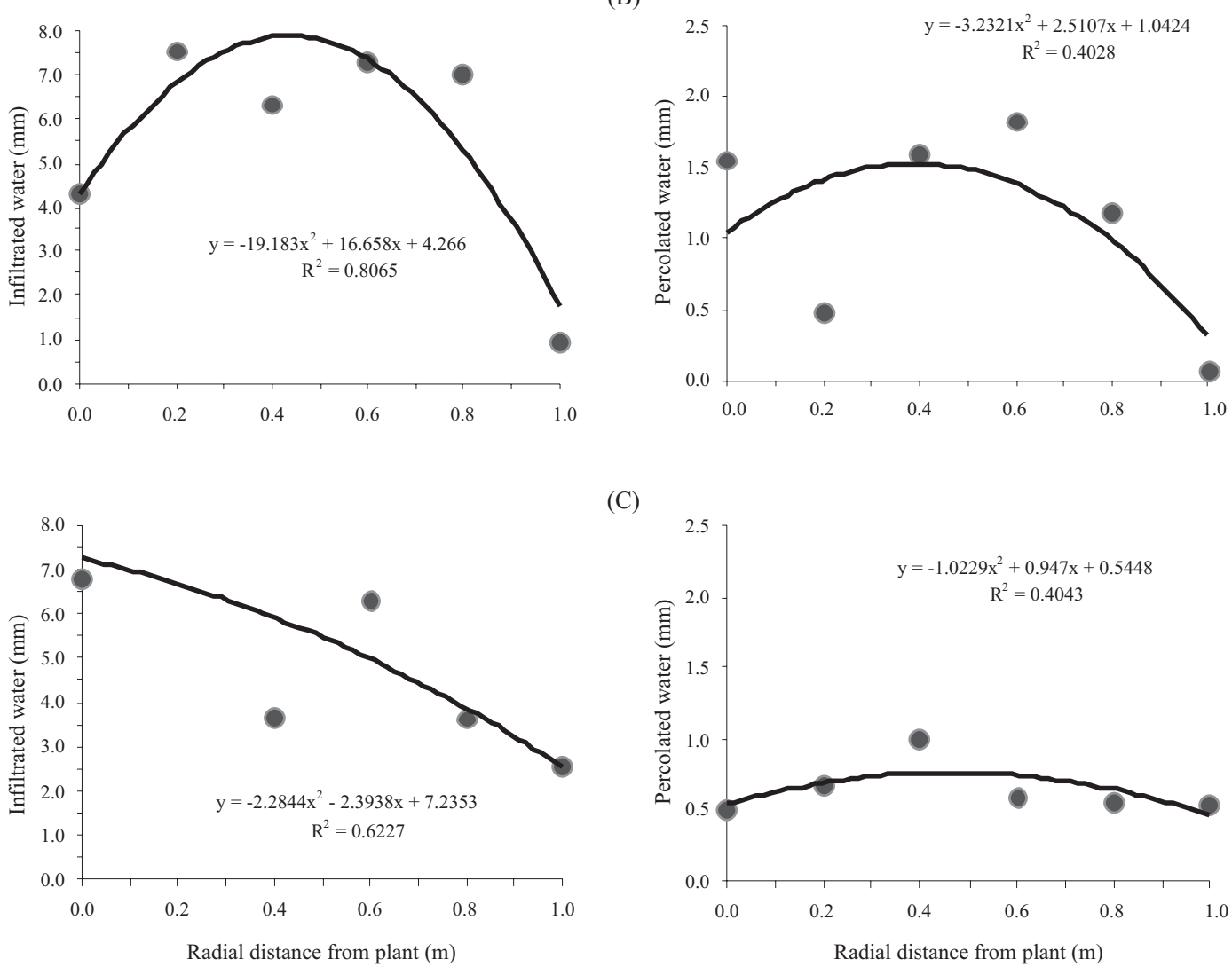

(C)

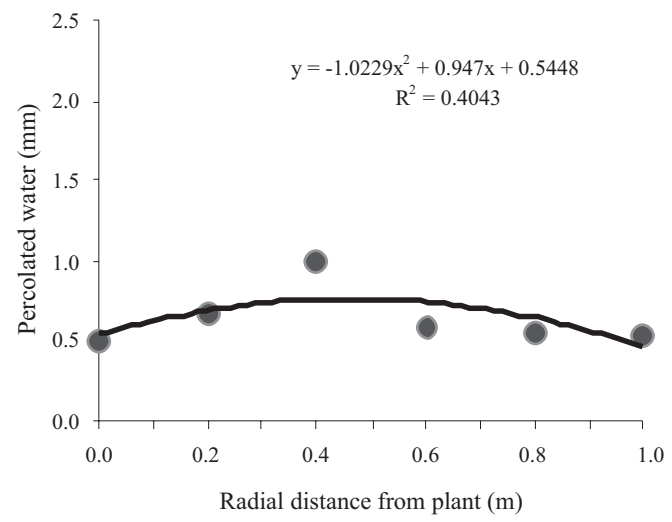

Figure 4. Infiltrated water and percolated water depths for treatment $\mathrm{T} 1$ (A, two 4- $\mathrm{L} \mathrm{h}^{-1}$ emitters per plant); T2 (B, four 4- $\mathrm{L} \mathrm{h}^{-1}$ emitters per plant); and T3 (C, five 4-L h $\mathrm{h}^{-1}$ emitters per plant) at different horizontal distances from the pseudostem. 
Table 2. Mean values of percolated water depth $(\mathrm{mm})$ at different times after the beginning of irrigation ${ }^{(1)}$.

\begin{tabular}{ccccccccc}
\hline Treatments $^{(2)}$ & \multicolumn{7}{c}{ Time after the beginning of irrigation (hours) } \\
\cline { 2 - 8 } & 1 & 2 & 4 & 6 & 8 & 10 & 12 \\
\hline T1 & $0.2518 \mathrm{a}$ & $0.0725 \mathrm{a}$ & $0.0486 \mathrm{a}$ & $0.1160 \mathrm{a}$ & $0.0288 \mathrm{a}$ & $0.0821 \mathrm{a}$ & $0.0399 \mathrm{a}$ & $0.0000 \mathrm{a}$ \\
T2 & $0.1109 \mathrm{~b}$ & $0.0510 \mathrm{a}$ & $0.1006 \mathrm{a}$ & $0.0270 \mathrm{a}$ & $0.0174 \mathrm{a}$ & $0.0397 \mathrm{a}$ & $0.0234 \mathrm{a}$ & $0.0094 \mathrm{a}$ \\
T3 & $0.1246 \mathrm{ab}$ & $0.0636 \mathrm{a}$ & $0.0414 \mathrm{a}$ & $0.0543 \mathrm{a}$ & $0.0317 \mathrm{a}$ & $0.0122 \mathrm{a}$ & $0.0252 \mathrm{a}$ & $0.0245 \mathrm{a}$ \\
\hline
\end{tabular}

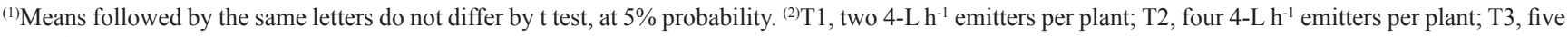
$4 \mathrm{~L}-\mathrm{h}^{-1}$ emitters per plant.

the period between 1 to 14 hours after the beginning of irrigation.

The average deep percolation in $\mathrm{T} 3$ was 52.5 and $41.8 \%$ smaller than the ones observed in $\mathrm{T} 1$ and $\mathrm{T} 2$, respectively. The water distribution pattern caused by the configuration of five emitters resulted in a good root distribution with water extraction occurring at all wetted volume under the plant (Figure 3). These results emphasize the assertion that the soil water distribution constitutes a decisive variable in the distribution of roots in the soil profile under drip irrigation, which is in agreement with Clothier \& Green (1994) and Coelho et al. (2002). Additional emitters and the resulting water distribution also influence the water application efficiency of an irrigation system. The average water application efficiency $\left(E_{a}\right)$ of T3 was the largest among the three studied systems: $92.5 \%$.

\section{Conclusions}

1. The number and placement of drip emitters significantly affect root and water distribution patterns in banana.

2. An increase in the number of the emitters in lateral lines promotes larger root zone distribution, larger water extraction, smaller losses by percolation flow, and larger water application efficiency.

\section{References}

ANDREU, L.; HOPMANS, J.W.; SCHWANK, L.J. Spatial and temporal distribution of soil water balance for a drip-irrigated almond tree. Agricultural Water Management, v.35, p.123-146, 1997.

ANUÁRIO brasileiro da fruticultura. Santa Cruz do Sul: Gazeta Santa Cruz, 2008.

BOHM, W. Methods of studying root systems. New York: Springer Verlag, 1979. 190p. (Ecological Studies, 33).

BORGES, A.L.; SOUZA, L. da S.; PEIXOTO, C.A.B.; SANTOS JÚNIOR, J.L.C. dos. Distribuição do sistema radicular da bananeira 'Prata-Anã' em duas freqüências de fertirrigação com uréia. Revista Brasileira de Fruticultura, v.30, p.259-262, 2008.

CLAESSEN, M.E.C. (Org.). Manual de métodos de análise de solo. 2.ed. Rio de Janeiro: Embrapa-CNPS, 1997. 212p. (Embrapa-CNPS. Documentos, 1).

CLOTHIER, B.E.; GREEN, S.R. Rootzone processes and the efficient use of irrigation water. Agricultural Water Management, v.25, p.1-12, 1994.

COELHO, E.F.; OLIVEIRA, F. das C.; ARAÚJO, E.C.E.; VASCONCELOS, L.F.L. Distribuição de raízes de laranja 'Pêra' sob sequeiro e irrigação por microaspersão em solo arenoso. Pesquisa Agropecuária Brasileira, v.37, p.603-611, 2002.

COELHO, E.F.; OR, D. Modelo de distribuição de água e de potencial matricial no solo sob gotejamento com extração de água por raízes. Pesquisa Agropecuária Brasileira, v.34, p.225-234, 1999.

COELHO E.F.; SANTOS D.B. dos; AZEVEDO, C.A.V. de. Sensor placement for soil water monitoring in lemon irrigated by micro sprinkler. Revista Brasileira de Engenharia Agrícola e Ambiental, v.11, p.46-52, 2007.

COELHO, E.F.; SANTOS, M.R.; COELHO FILHO, M.A. Distribuição de raízes de mamoeiro sob diferentes sistemas de irrigação localizada em Latossolo de Tabuleiros Costeiros. Revista Brasileira de Fruticultura, v.27, p.175-178, 2005.

CORDEIRO, Z.J.M. (Org.). Banana: produção, aspectos técnicos. Brasília: Embrapa Comunicação para Transferência de Tecnologia, 2000. 143p.

DOOREMBOS, J.; KASSAM, A.H. Efeito da água no rendimento das culturas. Campina Grande: UFPB, 1994. 306p.

FOOD AND AGRICULTURE ORGANIZATION OF THE UNITED NATIONS. Faostat: production: bananas. 2007. Available at: $<$ http://faostat.fao.org $>$. Accessed on: 3 July 2008.

GARCIA, R.V. Sistema radicular de bananeira irrigada por aspersão convencional e microaspersão no projeto Jaíba-MG. 2000. 47p. Dissertação (Mestrado) - Universidade Federal de Viçosa, Viçosa.

GREEN, S.R.; KIRKHAM, M.B.; CLOTHIER, B.E. Root uptake and transpiration: from measurements and models to sustainable irrigation. Agricultural Water Management, v.86, p.165-176, 2006.

HEIMOVAARA, T.J.; HUISMAN J.A.; VRUGT, J.A.; BOUTEN, W. Obtaining the spatial distribution of water content along a TDR probe using the SCEM-UA bayesian inverse modeling scheme. Vadose Zone Journal, v.3, p.1128-1145, 2004. 
HSIAO, T.C.; STEDUTO, P.; FERERES, E. A systematic and quantitative approach to improve water use efficiency in agriculture. Irrigation Science, v.25, p.209-231, 2007.

KASPAR, T.C.; EWING, R.P. Rootedge: software for measuring root length from desktop scanner images. Agronomy Journal, v.89, p.932-940, 1997.

KELLER, J.; BLIESNER, R.D. Sprinkle and trickle irrigation. New York: Van Nostrand Reinhold, 1990. 652p.

MMOLAWA, K.; OR, D. Root zone solute dynamics under drip irrigation: a review. Plant and Soil, v.222, p.163-190, 2000.

RAMOS, C.M.C. Distribuição do sistema radicular e consumo de água da bananeira irrigada por microaspersão. 2001. 62p. Dissertação (Mestrado) - Universidade Federal de Viçosa, Viçosa.

RITTER, A.; MUÑOZ-CARPENA, R.; REGALADO, C.M.; JAVAUX, M.; VANCLOOSTER, M. Using TDR and inverse modeling to characterize solute transport in a layered agricultural volcanic soil. Vadose Zone Journal, v.4, p.300-309, 2005.
ROGERS, D.H.; LAMM, F.R.; ALAM, M.; TROOIEN, T.P.; CLARK, G.A.; BARNES, P.L.; MANKIN, K. Efficiencies and water losses of irrigation systems. Manhattan: Kansas State University, 1997. (Irrigation Management Series).

SANTOS, D.B. dos; COELHO, E.F.; AZEVEDO, C.A.V. de. Absorção de água pelas raízes do limoeiro sob distintas freqüências de irrigação. Revista Brasileira de Engenharia Agrícola e Ambiental, v.9, p.327-333, 2005.

SILVA, A.J.P.; COELHO, E.F.; SANTOS, M.R.; PINHO, R.E.C.; COELHO FILHO, M.A. Distribuição e extração de água pela bananeira BRS Tropical submetida a diferentes sistemas de irrigação por gotejamento. In: CONGRESSO BRASILEIRO DE ENGENHARIAAGRÍCOLA, 35., 2006, João Pessoa. Agroenergia e desenvolvimento tecnológico: anais. João Pessoa: SBEA, 2006. 1 CD-ROM.

SOPHOCLEOUS, M. Global and regional water availability and demand: prospects for the future. Natural Resources Research, v.13, p.61-75, 2004.

Received on December 16, 2008 and accepted on June 24, 2008 